\title{
Malignant triton tumor of the lung, infiltrating the left atrium and left ventricle, with metastasis to the small intestine
}

\author{
Dariusz Tomaszewski ${ }^{1}$, Sebastian Beta ${ }^{2}$, Jan A. Rogowski ${ }^{3}$ \\ ${ }^{1}$ Department of Thoracic Surgery, University Clinical Centre, Gdańsk, Poland \\ 2Department of Cardiac Surgery, Swissmed Vascular, Gdańsk, Poland \\ ${ }^{3}$ Department of Cardiac and Vascular Surgery, Medical University of Gdańsk, Poland
}

Kardiochirurgia i Torakochirurgia Polska 2017; 14 (1): 52-54

\begin{abstract}
Malignant triton tumors are a rare subtype of malignant peripheral nerve sheath tumors showing rhabdomyosarcomatous differentiation. We report the case of a 33-year-old patient who underwent an excision of such a tumor by thoracic and cardiac surgery. He was reoperated on 1 month later because of a tumor of the small intestine and received adjuvant radiation.
\end{abstract}

Key words: triton tumor, primary lung cancer.

\section{Introduction}

Malignant triton tumors (MTT) are a rare subtype of malignant peripheral nerve sheath tumors (MPNST) with rhabdomyosarcomatous differentiation. They occur primarily within the head, neck, and torso [1]. So far, over 100 cases have been described in the literature; the overall 5-year survival was $14 \%$, while the rate of 5 -year survival among patients without synchronous metastases was $28 \%$ [2]. The occurrence of an MTT within the chest is very rare [3].

This paper presents the case of a 33-year-old patient who underwent an urgent surgical procedure due to a primary MTT of the right lung, infiltrating the left atrium and left ventricle of the heart.

\section{Case report}

The 33-year-old patient, whose medical history included perineo-abdominal excision of the rectum due to schwannoma of the left buttock, was referred to the clinic with the diagnosis of a tumorous/nodal mass of the right pulmonary hilum and mediastinum, infiltrating the left atrium and left ventricle. No histopathological diagnosis was reached on the basis of the samples obtained with fineneedle transthoracic biopsy and bronchoscopy. The patient complained of significant fatigue, resting dyspnea, and cough. On physical examination, the patient appeared seri-

\section{Streszczenie}

Guz Trytona to rzadki podtyp złośliwego guza osłonek nerwów obwodowych, którego komórki wykazują zróżnicowanie mięsaka prążkowanokomórkowego. Przedstawiamy przypadek 33-letniego chorego, u którego wycięto takiego guza w trakcie jednoczesnej operacji torako- i kardiochirurgicznej. Miesiąc później pacjent był ponownie operowany z powodu guza jelita cienkiego, a następnie poddany radioterapii.

Słowa kluczowe: guz Trytona, pierwotny nowotwór płuca.

ously ill (tachypnea, arterial blood pressure: 100/50, heart rate: $100 \mathrm{bpm})$. Laboratory blood tests, chest computed tomography (CT) with contrast, echocardiography, abdominal ultrasound, and bronchoscopy were performed (Figs. 1, 2).

Chest CT revealed a tumorous/nodal mass occupying the hilum and segment 2 of the right lung and infiltrating the mediastinum (size: $48 \times 96 \times 99 \mathrm{~mm}$, radiodensity: approx. 30 Hounsfield unit (HU) with no significant enhancement after the administration of contrast), clearly pressing on the right superior lobe bronchus, the superior vena cava, and the azygos vein. The mass entered the left atrium, resulting in a filling defect $35 \times 69 \times 47 \mathrm{~mm}$ in size; infiltration into the left ventricle could not be excluded. There was a scant amount of fluid in the pericardial sac. Fluid was present in both pleural cavities from the apex to the diaphragm; the fluid layer was $38 \mathrm{~mm}$ thick on the left side and $32 \mathrm{~mm}$ on the right side. Echocardiographic examination demonstrated that the size of the left atrium was increased; within its lumen, there was a ballotable mass (size: $71 \times 45 \mathrm{~mm}$ ) exiting the right superior pulmonary vein and entering the left ventricle through the mitral valve. The average mitral valve gradient was $16 \mathrm{~mm} \mathrm{Hg}$. Bronchoscopy demonstrated that the opening of the bronchus of the right lung's $2^{\text {nd }}$ segment was obstructed due to external compression, which was accompanied by mucosal 


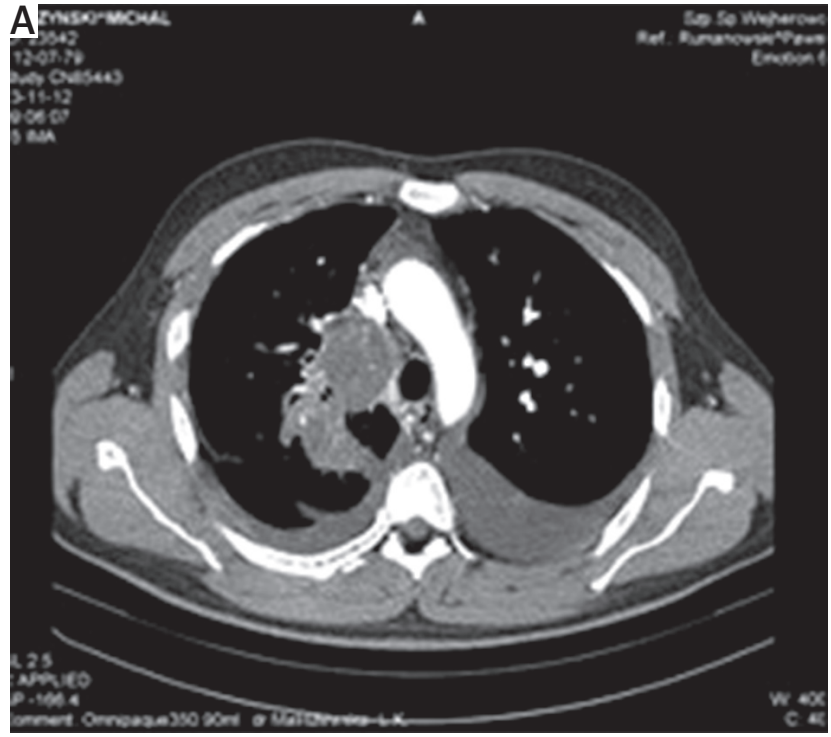

Fig. 1. A, B - Tumor infiltrating the mediastinum

edema. Abdominal ultrasound did not show any pathological changes.

The patient was qualified for urgent surgery by the cardiothoracic surgical team. The procedure was performed with the patient lying in the supine position under general endotracheal anesthesia; the chest was opened with a longitudinal, superomedial incision of the sternum. The pleural cavities were opened, and the fluid was evacuated. After the superior and inferior venae cavae and the ascending aorta were cannulated in a typical fashion under extracorporeal circulation, the wall of the left atrium was incised above the venous confluence via a left atrial approach. The tumor and its pedicle growing out of the right superior pulmonary vein were removed without injuring the vascular wall. The atrial wall was sewn together with a continuous

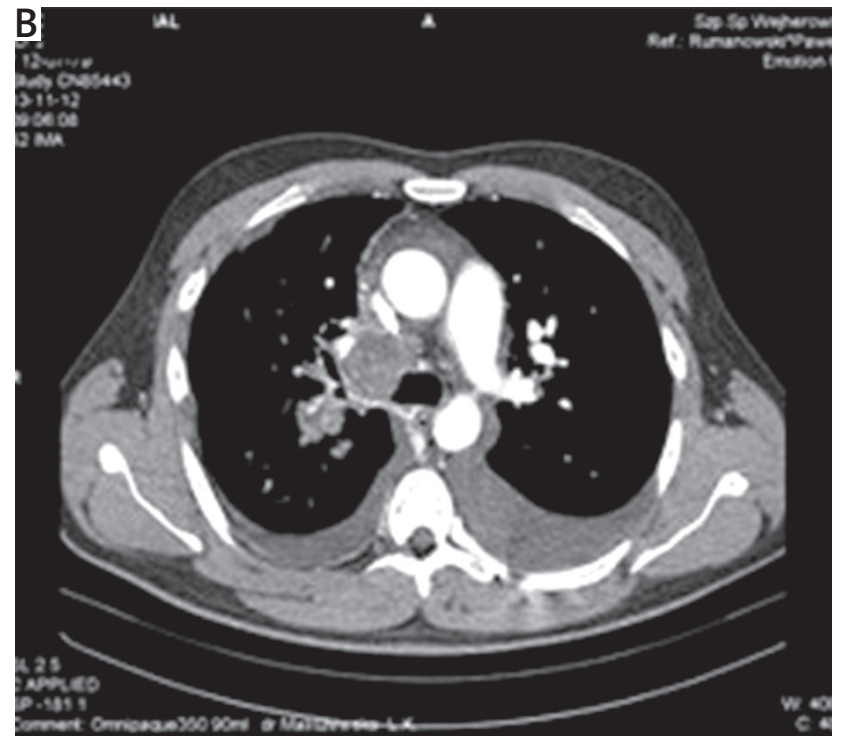

Prolene 4.0 suture. Extracorporeal circulation was discontinued without any problems. After heparin was reversed with protamine, the thoracic stage of the surgery began. Due to the extensive neoplastic infiltration and the significant risk of injuring important structures of the pulmonary hilum and mediastinum, a decision was made to close the sternum and continue the surgery using right posterolateral thoracotomy through the $5^{\text {th }}$ intercostal space. The infiltration posed considerable technical difficulties; the upper lobe was excised, and mediastinal lymphadenectomy was performed. The postoperative course was complicated by a residual chamber filled with air and fluid in the pleural cavity, which was successfully treated with pleural drainage. The patient was discharged home on the $10^{\text {th }}$ postoperative day in good general condition.
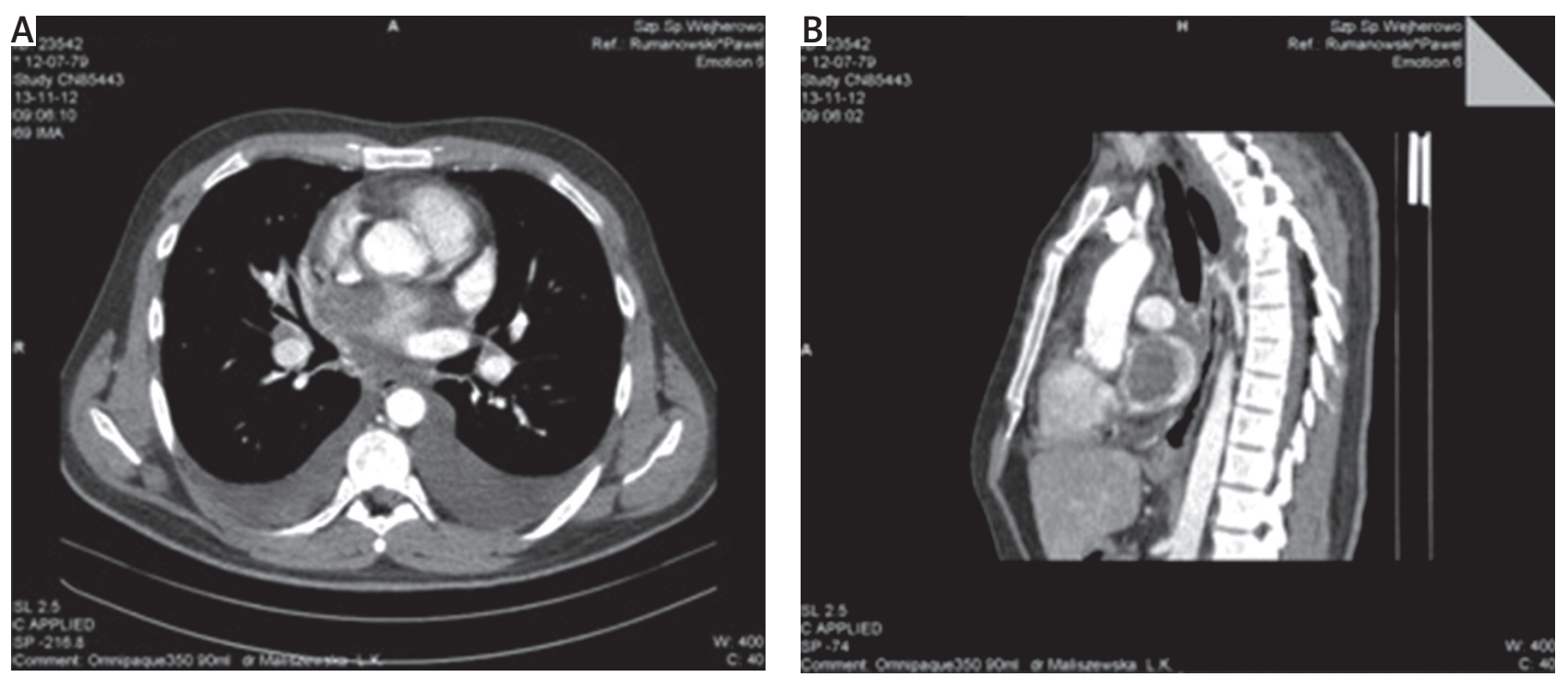

Fig. 2. A, B - Tumor in the left atrium 
Histopathological examination yielded the diagnosis of a triton tumor - a malignant peripheral nerve sheath tumor with heterologous rhabdomyoblastic differentiation. Neoplastic cells were found in the bronchial resection margin (R1). The lymph nodes and the fragment of the superior pulmonary vein were free from neoplastic infiltration. The sample was consulted with Professor C.D. Fletcher (Harvard University, Boston, USA).

Before the start of oncological treatment, one month after the surgery, a PET scan revealed a tumor of the small intestine, which was excised surgically. Microscopic analysis confirmed the presence of an MTT metastasis in the mesentery of the small intestine.

\section{Discussion}

The MPNST is a malignant sarcoma originating from Schwann cells in peripheral nerve sheaths; in approximately $50 \%$ of cases, it develops in patients with neurofibromatosis type 1 (NF1), and 5-year survival is achieved in 34\% of patients [2]. The MPNST is observed in various areas of the body, but most cases involve the torso and the extremities [4].

The MTT is a rare subtype of MPNST ( $<10 \%$ of cases) whose cells show rhabdomyosarcomatous differentiation and are characterized by more malignant progression. The first description of an MTT comes from 1938, while the name was coined by Woodruff et al. in 1973 [5]. Based on an analysis of 124 MTT cases, McConnell and Giacomantonio [2] reported that the overall 5-year survival rate was $14 \%$, the median survival time was 13 months, and the rate of local recurrence/progression was 50\% (the median time to recurrence/progression was 6 months); furthermore, 31.4\% of patients had distant metastases, primarily to the lungs (the median time to metastasis occurrence was 11 months). Multifactorial analysis demonstrated that neoplastic presence in the resection margin, local recurrence, and distant metastases had a significant influence on mortality in this group of patients, while the use of adjuvant radiation therapy significantly prolonged survival.

In very rare cases (<10\%), MTT occur within the mediastinum, lungs, and heart, as described in individual case reports [6-9].

In our patient, the MTT was a primary lung tumor, which filled the left atrium completely as a result of its expansion. We have found no similar cases in the literature. Transthoracic needle biopsy and bronchofiberoscopy with sample acquisition were unsuccessful in establishing the diagnosis of the tumor. It appears that, due to the complex nature of neurogenic tumors, these examinations are unable to determine the lesion's character (benign or malignant), although they are helpful in providing differentiation with other nosological entities. Apart from the stan- dard methods such as CT, nuclear magnetic resonance, and echocardiography, imaging diagnostics should also include a positron emission tomography (PET) scan, which can reveal distant metastases concomitant with the primary lesion. Their presence is associated with significantly worse prognosis [2]. In the described case, a PET scan was not performed due to the intensified symptoms of circulatory insufficiency and the consequent urgency of surgical treatment. After a month, a PET scan was performed before the patient was qualified for adjuvant oncological treatment, revealing a metastasis to the small intestine, which was resected surgically. It cannot be excluded that the metastatic focus may have originated from a fragment of the tumor in the left atrium, which detached before or during the surgery (embolic mechanism).

\section{Conclusions}

We have presented the case of a young patient with a locally advanced, very rare, primary malignant lung tumor. Surgical treatment was performed due to the threat to the patient's life. Due to the short duration of follow-up, we can only evaluate the short-term results. The patient's condition improved sufficiently for him to continue oncological treatment. We believe that attempting surgical treatment in patients whose clinical and radiological presentation is uncertain is justified in all such cases.

\section{Disclosure}

Authors report no conflict of interest.

\section{References}

1. Brooks JS, Freeman M, Enterline HT. Malignant Triton tumor, natural history and immunohistochemistry of nine new cases with literature review. Cancer 1985; 55: 2543-2549.

2. McConnell YJ, Giacomantonio CA. Malignant triton tumors, complete surgical resection and adjuvant radiotherapy associated with improved survival. J Surg Oncol 2012; 106: 51-56.

3. Lang-Lazdunski L, Pons F, Jancovici R. Malignant "triton“ tumor of the posterior mediastinum: prolonged survival after staged resection. Ann Thorac Surg 2003; 75: 1645-1648.

4. Ducatman BS, Scheithauer BW, Piepgras DG, Reiman HM, IIstrup DM. Malignant peripheral nerve sheath tumors. A clinicopathologic study of 120 cases. Cancer 1986; 57: 2006-2021.

5. Woodruff JM, Chernik NL, Smith MC, Millett WB, Foote FW Jr. Peripheral nerve tumors with rhabdomyosarcomatous differentiation (malignant "Triton " tumors). Cancer 1973; 32: 426-439.

6. Moran CA, Suster S, Koss MN. Primary malignant "triton" tumour of the lung. Histopathology 1997; 30: 140-144.

7. Suzuki T, Suzuki S, Kamio Y, Hori G, Tomita S, Suzuki H, Mitsuya T, Tate G, Sagawa F. A case of malignant triton tumor of the lung. Thorac Cardiovasc Surg 1996; 44: 319-320.

8. Bose AK, Deodhar AP, Duncan AJ. Malignant triton tumor of the right vagus. Ann Thorac Surg 2002; 74: 1227-1228.

9. Kabir S, Kapetanakis El, Shabbo F. Intracardiac malignant triton tumor: a first presentation. Ann Thorac Surg 2010; 89: 968-969. 